Financial Statistical Journal (2018) Volume 1 doi:10.24294/fsj.v1i3.971

\title{
Merger Waves: Are Buyers Following the Herd or Responding to Structural Queues?
}

Ralph Mark Sonenshine

American University, United States

\begin{abstract}
While there has been a significant amount of research covering the causes of merger waves, few papers have rank ordered merger waves based on the causes nor sought to determine which rationale leads to higher bidder payouts. This paper seeks to fill this gap by examining a cross section of large mergers across most industries occurring over a 17 year period. I find that merger waves over this period are caused foremost by changing economic and regulatory conditions. It is the behavioral rationale of mispricing, however, that more often leads to higher bidder payouts or merger premiums among acquirers in merger waves.
\end{abstract}

Keywords: Mergers and Acquisitions; Merger Premium; Neoclassical; Behavioral

\section{Introduction}

Scholars have long noticed the clustering of mergers, called merger waves, over a period of time (e.g. a large number of mergers among oil and gas and electric utility companies occurred in the late 1990s and early 2000s). Many scholars have attributed merger waves to three key structural factors: deregulation, economic change, and technological change. Others, however, attribute merger waves less to structural changes and more to a herding effect brought on by mis-valuation. Schools of thought regarding merger waves can thus be grouped into neoclassical theory, emphasizing economic, regulatory, or technological, change, and behavioral theory, focusing on mis-valuation of targets and acquirers.

Structural change can result in mergers as markets evolve to favor one technology or product over another. As a result firms with obsolete technologies may need to restructure or merge, while companies with a leading market share may seek to consolidate their position by acquiring rival companies. Changes in economic conditions, such as a rapid change in commodity prices, can also cause firms, particularly those that are financially unstable, to seek out merger partners. The rationale is that during times of rising commodity prices, some firms might seek to expand and increase their debt loads. Then, as commodity prices suddenly decline, these debt-ridden firms struggle to remain solvent and feel the need to shed assets. Often technological disruption are the cause of changing economic conditions, with both trends leading to merger waves.

Also, industry deregulation may spark merger waves as firms seek to take advantage of new market rules. Deregulation might eliminate or greatly reduce price and/or quantity restrictions, which could tempt companies to merge as they try to take advantage of the new rules. As such, deregulation could spur a frenzy of activity as firms seek to enter markets where they were previously barred.

In opposition to the structural view is the notion that mis-valuation of companies is actually the primary driver of merger waves. Under this argument management observes the long run potential in an industry, but investors do not. This difference can be found in diversions in valuation, (e.g. high market to book value ratios) as well as variations in the dispersion in valuations from the mean. Following this theory, acquirers believe that firms are undervalued, and they need to respond quickly to consummate the merger before investors realize the underlying value of the firm. The argument that merger clustering are caused by mis-valuation of firms can also be used to explain aggregate versus industry specific merger waves. 
So which rationale, the structural or behavioral, tends to be the primary cause of merger waves? Are there differences in the synergies perceived or value placed on merger targets as seen in the merger premium if mergers are in versus out of a wave? This paper explores these questions by estimating the impact that structural and behavioral factors have on the likelihood of a merger wave as well as on the merger premium or the deviation between the market value of the firm and the private value of the firm to the acquirer. I find that while both behavioral and structural factors can impact the likelihood of a merger wave ensuing, it is the structural variables that have the greatest impact on both probability of a merger wave as well as on the deal premium offered. In addition, I find differences in the factors impacting a merger wave based on whether the merging companies is part of an industry, defined as regulated, versus one classified as unregulated. Finally, I find that behavioral factors seem to have a greater impact on the acquire's willingness to pay a premium for the target, when the merger is part of a merger wave; in contrast, structural factors influence the merger premium to a greater extent when the merger is not part of a merger wave.

\section{Literature Review}

Brealey and Myers (1996) in their seminal textbook comment that merger waves defy explanation. This statement may have been a clarion call to scholars to study the clustering of mergers.

\subsection{Behavioral Theory}

Some scholars viewed merger waves to be primarily associated with stock market valuation. Schleiffer and Vichney (2003) argue that bull markets lead bidders with overvalued stock to make acquisitions, as acquirers believe their best option is to use their equity to buy assets, perceived to be undervalued. Rhodes-Kropf and Viswanathan (2004) add that concentrated merger activity can be rationally attributed to over and under accumulation of stock among investors due to a mismatch of private information among sellers and buyers.

The view that stock market values prompt merger activity was termed by Harford (2004) as the behavioral explanation, in comparison to the neoclassical argument for merger waves, which emphasizes economic, technological, and regulatory shocks. The rationale behind the behavioral view is that while the level of value that the bidder places on the target is predicated on the market condition, the more overvalued the market, the larger the disparity for overvaluation of the target. Rhodes-Kropf and Viswanathan (2004) explain that an overvalued target is due both to market overvaluation as well as firm specific effects; the target cannot differentiate between the two effects. The target, therefore under weights the market effect when the market is overvalued and over weights it when the market is undervalued. Mergers, they argue, get consummated due to asymmetric information between the buyer and seller regarding the potential synergies between the two companies. As a result, mergers, Rhodes-Kropf and Viswanathan (2004) predict, are more likely to occur in overvalued markets or sectors, and relatively undervalued targets are more likely to sell. In addition, Harford (2004) and Andrade et. al. (2002) speculate that merger waves will coincide with a higher fraction of stock versus cash used to finance the merger than occurred in prior period mergers. Thus, mergers financed by stock purchases will occur to a greater extent in overvalued markets, suggesting that merger waves are more likely to be accompanied by stock-financed mergers than out-of-wave mergers. The behavioral argument can be summarized in the following table.

\begin{tabular}{|l|l|l|l|l|}
\hline Merger Wave & Market value & Target Firm value & Acquiring Firm & Financing method \\
\hline More likely to occur & Overvalued & $\begin{array}{l}\text { Undervalued, } \\
\text { Low Tobin's Q }\end{array}$ & $\begin{array}{l}\text { Overrvalued, } \\
\text { High Tobin's Q }\end{array}$ & More stock \\
\hline Less likely to occur & Undervalued & $\begin{array}{l}\text { Overvalued, high } \\
\text { Tobin's Q }\end{array}$ & $\begin{array}{l}\text { Undervalued, low } \\
\text { Tobin's Q }\end{array}$ & More cash \\
\hline
\end{tabular}

Table 1. Behavioral merger wave paradigm

Schleifer and Vichney (2003) add that managers with perfect information take advantage of deviations from value that occur in the stock market. As such, acquirers purchase firms with their overvalued stock in periods of high market valuations and use cash in periods of low market valuations; the authors also contend that the merged company will 
underperform once the merger wave ends. Schleifer and Vichney (2003) argue that merger waves are characterized by rational managers and inefficient markets; this theory can be viewed as diametrically opposed to Roll's (1996) hubris notion whereby the market is efficient, but managers act irrationally in pursuit of acquisition targets.

Jovanovic and Rousseau (2002) add to the argument by detailing the valuation metrics that spur merger waves whereby firms with high Tobin's Q ratios buy companies with relatively low Tobin's Q levels. In doing so, the acquirer expects the market to reprice the low Tobin's Q assets post-merger to the acquirer's level. Each wave, they argue, is, therefore, preceded by a rise in the dispersion of Tobin's Q.

A related behavioral explanation of merger waves termed the managerial discretion theory is that managers gain utility from expanding their company. Gugler et. al (2012) assert that "under the managerial discretion theory, merger waves occur during stock market booms, because the optimism prevailing in the market allows growth-seeking managers to undertake more wealth-destroying mergers than they safely can under normal conditions."

\subsection{Structural hypothesis}

The structural hypothesis for merger change centers on three explanations: technological, economic, and regulatory. Harford (2004) finds that technological, economic, or regulatory shocks can lead to merger waves if these events are accompanied by higher capital liquidity levels in the industry. As such, Harford (2004) claims that merger waves have been misattributed to behavioral explanations of market value mismatch when, in fact, they are due to industry shocks accompanied by high capital liquidity, as measured by loan spreads between commercial and federal funds rates as well as the market to book value ratios.

Ovtchinnikov (2013) adds that merger waves are due in large part to industry deregulation, which occurs as regulators respond to poor industry conditions, e.g. oil shocks causing poor industry performance. Deregulation may also occur after technological or other structural changes. Deregulation removes exit barriers, thus resulting in mergers of struggling firms in these underperforming industries. Ovtchinnikov's (2013) findings suggest that post deregulation, mergers result in higher cash financing, a higher number of bankruptcy mergers and lower merger premiums.

Mitchell and Mulherin (1996) view merger waves to result from industry shocks - changing financing techniques, deregulation, and changing input prices that affect the number and size of firms. Firms then respond to shocks by internal or external change. Corporate takeovers, Mitchell and Mulherin (1996) contend, are a low cost alternative to respond to these changing industry conditions.

\subsection{Summary}

Clearly, there are a multitude of explanations for merger waves. This paper adds to the literature by testing these merger wave theories and segmenting the factors impacting merger waves by regulated versus unregulated industries. I hypothesize factors spurring a merger wave differ by industry type, particularly whether the industries are highly regulated or not. As such, some of the discrepancy in the arguments regarding the causes of merger waves is due to the composition of the segments being studied. In addition, this paper adds to the literature by assessing the relationship between merger waves and merger premiums and examining whether the factors that impact the merger premium differ between mergers in and out-of-wave.

\section{Hypothesis, Data and Empirical Methodology}

\subsection{Hypothesis}

This paper assesses the impact of structural and behavioral factors on the probability that a merger wave will occur and on the merger premiums paid to effectuate the merger. Accordingly, I hypothesize that,

1. Merger waves occur primarily as a response to economic and regulatory change rather than as a result of behavioral factors.

2. The factors that influence the likelihood of a merger wave ensuing will vary depending on the industry type, specifically on whether the industry is classified as regulatory or not.

3. Merger premiums are influenced by the presence of a merger wave; additionally the factors that impact the merger wave will vary depending on the presence of a merger wave or not. 


\subsection{Data}

This study covers 5,679 mergers in 35 industries with transaction values greater than $\$ 1$ billion from 2000 through 2016 in which over $50 \%$ of the public company was acquired by another public company. The data was gathered from Thomson Reuthers Mergers and Acquisitions data base. The total number of mergers by industry over the 17 year time period are shown in the Appendix, with the last two columns identifying the year (s) of the merger wave and the number of mergers occuring in the wave.

Merger waves were identified if the two year merger total $\left(\mathrm{M}_{\mathrm{t}}+\mathrm{M}_{\mathrm{t}-1}\right)$ was found to be greater than two standard deviations away from the two year average of mergers within the 17 year time period.

\begin{tabular}{|l|l|l|}
\hline Year & Yearly number of mergers & $\begin{array}{c}\text { Two year number } \\
\text { of mergers } \mathbf{M}_{\mathbf{t}}+\mathbf{M}_{\mathbf{t}-\mathbf{1}}\end{array}$ \\
\hline 2010 & 18 & 26 \\
\hline 2011 & 25 & 43 \\
\hline $\begin{array}{l}\text { Average } \\
\text { Standard deviation }\end{array}$ & 21 & 18 \\
\hline
\end{tabular}

Table 2. Example of identifying a merger wave - mining

For example, in 2010 and 2011 years, 43 mergers in mining were announced. The 43 merger count is more than two standard deviations (22) away from the average, two-year count of the number of mergers (18) in mining. In this case, the merger wave would be in $2011\left(\mathrm{M}_{\mathrm{t}}\right)$ and in $2010\left(\mathrm{M}_{\mathrm{t}-1}\right)$. A merger wave can also be identified if the one year merger count is greater than two standard deviations away from the one year average even if the two year average is not above two standard deviations away from the two year mean.

Over the 17 year period there were 5,679 mergers identified, $14.8 \%$ or 839 occurring in a merger wave as shown in the frequency distribution.

\begin{tabular}{|l|l|l|}
\hline Merger wave & Percent Merger wave & $\begin{array}{l}\text { Number of mergers in or } \\
\text { out-of-wave }\end{array}$ \\
\hline Yes & $14.8 \%$ & 839 \\
\hline No & $85.2 \%$ & 4,840 \\
\hline & $100 \%$ & 5,679 \\
\hline
\end{tabular}

Table 3. Frequency of merger wave

The following graph shows the number of mergers overall by year and the number of mergers in and out-of-wave by year.

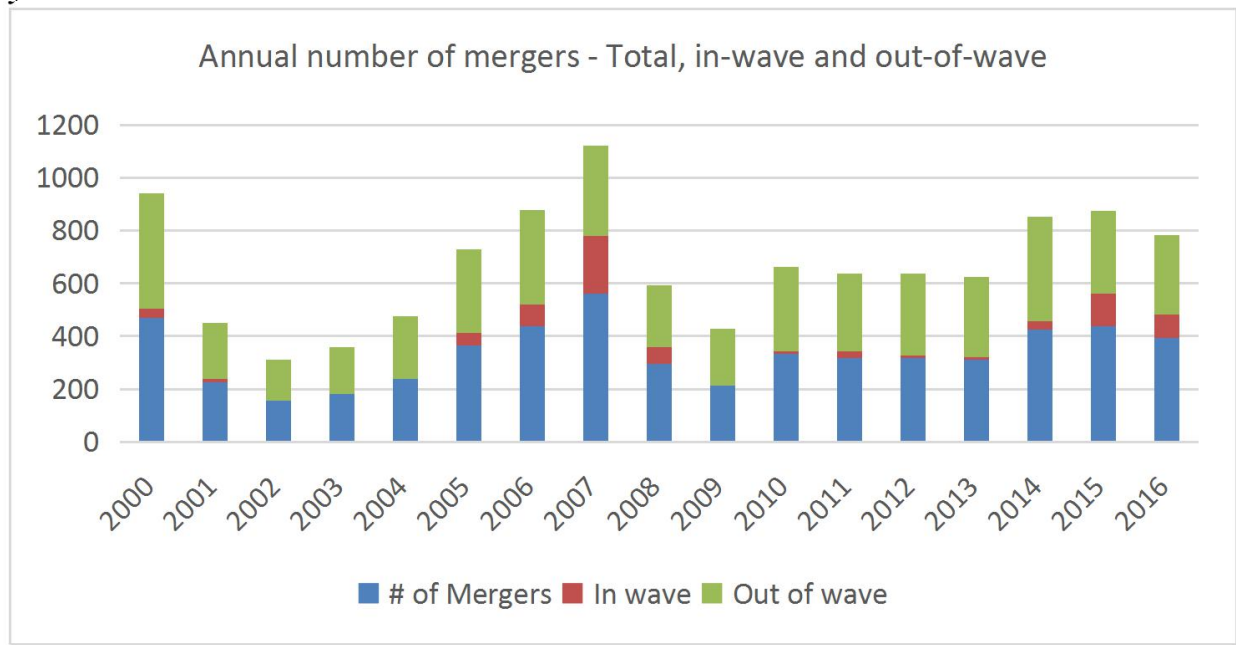

Here we see that the peak number of mergers occurred in the years 2000 and 2007, both just prior to the recessions of 2001 and 2008. The number of mergers in-wave were clustered in two three to four year periods 2005-2008 and 
2014-2016. The first merger wave cluster was dominated by financial mergers, while the second merger wave cluster included a variety of industries.

Per the definition used by Ovtchinnikov (2013), six of the larger industries (oil and gas, telecommunications, financial services, trucking, utilities, and health care, were classified as regulated industries, with the other 29 industries being unregulated. The following chart shows the percent of merger waves occurring in regulated versus non-regulated industries.

\begin{tabular}{|l|l|l|l|}
\hline Binary Variable & \# of mergers & \% Merger wave & $\begin{array}{l}\text { Average 1 month } \\
\text { Deal }\end{array}$ \\
\hline Regulated industries & 2,985 & $13 \%$ & $26 \%$ \\
\hline Non regulated & 2,694 & $17 \%$ & $38 \%$ \\
\hline
\end{tabular}

Table 4. Segmentation of Merger Wave and Deal Premium

We see from the chart that the number of mergers identified to be in regulated versus unregulated industries was fairly similar. From the table one also sees that a larger percent of merger waves occurred in non-regulated industries though the percentages are fairly close. In addition, the deal premium was higher in non-regulated versus regulated industries. The one month deal premium is defined as the percent difference between the market value one month ago and the amount the acquirer offers for the firm at the time of the merger announcement.

The results from this table would initially suggest that, as opposed to Mulhern and Mitchell (1996) and Ovtchinnikov's (2009) findings, merger waves are more likely to be found in non-regulated industries, perhaps because the growth potential in regulated industries is more limited. In addition, the average deal premium in non-regulated industries is higher suggesting acquirers are more optimistic about the potential synergies from mergers in non-regulated industries. The 35 industries were grouped into six sectors as shown below.

\begin{tabular}{|l|l|l|l|}
\hline Sectors & Observations & \% In-wave mergers & $\begin{array}{l}\text { Percent One Month } \\
\text { Deal Premium }\end{array}$ \\
\hline Finance industry & 1.421 & $14 \%$ & $24 \%$ \\
\hline Commodity industry & 723 & $8 \%$ & $36 \%$ \\
\hline Manufacturing industry & 1.014 & $16 \%$ & $36 \%$ \\
\hline Food and Drug & 555 & $15 \%$ & $42 \%$ \\
\hline Business service & 1.312 & $17 \%$ & $34 \%$ \\
\hline Consumer service & 654 & $17 \%$ & $26 \%$ \\
\hline Total & 5.679 & $15 \%$ average & $32 \%$ average \\
\hline & & & $(2,278$ observations $)$ \\
\hline
\end{tabular}

Table 5. Segmentation of merger wave and deal premium by industry and method of financing

From Table 5 it appears that the percent of merger waves is similar among sectors, except for the commodity sector, with only $8 \%$ of the mergers being in a wave. We also see a fair amount of difference in the merger premiums by sector.

The likelihood of a merger wave as well as the deal premium amount were also found to vary based on the financing method as shown in Table 6.

Here we see that the majority of transactions were financed by cash. The average deal premium with these transactions and all mergers is $31 \%$ to $32 \%$ respectively, with little variation between in-wave (column 5) versus out-of-wave (column 6) mergers. The second largest category of mergers were those financed by borrowing and cash. Here, we see again roughly $14 \%$ of the mergers with this manner of financing occurred in-wave, but the deal premiums were higher in-wave versus out-of-wave. The next largest category of financing were those with either stock issuance and cash, stock and borrowing or debt and cash. In these cases the percent of mergers occurring in-wave was higher, ranging from $19 \%$ to $23 \%$ but the differences in deal premiums between in and out-of-wave vary, making an apparent 
trend indiscernible. In fact, overall there is no discernable difference in the deal premium between in-wave and out-of-wave mergers except of the category of deals financing by borrowing.

Next, we turn to an examination of summary data for continuous variables as shown in Table 7.

\begin{tabular}{|l|l|l|l|l|l|}
\hline Variable & Observations & $\begin{array}{l}\text { \%Merger } \\
\text { wave }\end{array}$ & $\begin{array}{l}\mathbf{1} \text { month deal } \\
\text { premium }\end{array}$ & $\begin{array}{l}\mathbf{1} \text { month } \\
\text { premium } \\
\text { in-wave }\end{array}$ & $\begin{array}{l}\mathbf{1} \text { month deal premium } \\
\text { out-of-wave }\end{array}$ \\
\hline Stock \& cash & 365 & $19 \%$ & $31 \%$ & $31 \%$ & $31 \%$ \\
\hline Stock, borrow & 130 & $23 \%$ & $31 \%$ & $38 \%$ & $28 \%$ \\
\hline Stock, debt & 31 & $19 \%$ & $40 \%$ & $26 \%$ & $43 \%$ \\
\hline Stock, debt, borrow & 8 & $25 \%$ & $34 \%$ & $32 \%$ & $35 \%$ \\
\hline Debt \& cash & 128 & $23 \%$ & $34 \%$ & $29 \%$ & $36 \%$ \\
\hline Debt, borrow & 30 & $23 \%$ & $36 \%$ & $36 \%$ & $37 \%$ \\
\hline Borrow \& cash & 800 & $14 \%$ & $35 \%$ & $42 \%$ & $31 \%$ \\
\hline Cash & 4.187 & $14 \%$ & $31 \%$ & $30 \%$ & $31 \%$ \\
\hline Total & 5,679 & $15 \%$ & $32 \%$ & $33 \%$ & $32 \%$ \\
\hline
\end{tabular}

Table 6. Percent merger wave and deal premium by method of financing

\begin{tabular}{|l|l|l|l|l|}
\hline Continuous variables & \# of Observations & In merger wave & Out of merger wave & Total \\
\hline Log quantity index & 5,639 & 4.76 & 4.65 & 4.67 \\
\hline Percent change in & 5,639 & $1.95 \%$ & $2.4 \%$ & $2.3 \%$ \\
\hline IRR index & 4,398 & 21,615 & 29,010 & 28,373 \\
\hline IRW index & 4,398 & $1,952,952$ & $2,597,732$ & $2,544,829$ \\
\hline Forward S\&P 500 PE & 5,639 & 25.38 & 23.95 & 24.16 \\
\hline Deal Value & 5,639 & $\$ 2,177$ & $\$ 1,928$ & 1,963 \\
\hline Acquirer Tobin's Q & 1,874 & 6.25 & 8.62 & 8.5 \\
\hline Target Tobin's Q & 1,533 & 5.56 & 6.25 & 5.76 \\
\hline
\end{tabular}

Table 7. Segmentation of Merger Wave by Continuous Variables

Here we see that the $\log$ of the quantity index is roughly 4.67 with a slightly higher amount for in-wave mergers, suggesting that in-wave mergers may be occurring to a greater extent in faster growing industries. Similarly, we see a large difference in the percent change in prices between in-wave and out-of-wave mergers indicating perhaps that in-wave mergers occur in response to price declines. We also see in Table 7 that the RegData, Quantgov regulation indicators, industry relevant restrictions (IRR) and industry relevant words (IRW) are considerably higher for out-of-wave versus in-wave mergers. The IRR and IRW indicators capture the restrictiveness of regulations by industry with the former tagging the number of regulations and the latter tagging the number of words in all of the regulations. These averages suggest that merger waves are more prevalent in less regulated industries. In addition, we see that the average transaction size of a merger is higher in-wave than out-of-wave and the forward PE ratios are higher in-wave than out-of-wave, suggesting that merger waves tend to involve larger deals and occur when the stock market values, as measured by projected PE ratios, are higher.

Finally, we see in Table 7 the average Tobin's Q amounts (measured by market value/book value) for acquirers and targets over the sample period. Acquirer and target Tobin's Q were segmented for in-wave and out-of-wave mergers. We see from the chart that average target Tobin's Q amounts are lower than acquirer amounts. We also observe from the chart that the in-wave merger wave average Tobin's Q levels are lower for both targets and acquirers than the out-of-wave Tobin's Q amounts. I will investigate the significance of the variation in and outside of a merger wave in 
the regression analysis. It is also noteworthy to point out that Tobin's Q data was limited for acquirers and targets. As such, regressions were run on two samples, a small sample includes Tobin's Q data, and a large sample that does not include Tobin's Q data.

\subsection{Regression Methodology}

To assess the impact of structural versus behavioral factors on the likelihood that a merger wave will occur, I employ the following logit binary choice model.

$$
\text { MergerWave }_{j}=\beta_{0}+\beta_{1} \text { Behavioral }_{j}+\beta_{2} \text { Regulatory }_{j}+\beta_{3} \text { Economic }_{j}+\beta_{4} \text { Segment }_{j}+\varepsilon \text { (1) }
$$

In this model MergerWave is a dummy variable with a 1 indicating the merger is part of a merger wave and a 0 signifying the merger is out-of-wave. $J$ refers to the individual mergers. Behavioral in equation (1) is a vector of variables covering company and market valuations as well as method of financing. Company-specific valuation variables consist of the acquirer's Tobin Q measured by market value/book value per share and difference in Tobin's $\mathrm{Q}$ between the acquirer and target. Per the behavioral hypothesis, low Tobin's Q for the target or large differences in Tobin's Q between the acquirer and target could correlate with a merger wave, as acquirers flock to take advantage of perceived mis-valuation in the market. In addition, I include the method of financing the deal, under the notion, per Harford (2004) and Andrade et al. (2002), that a greater number of mergers financed with debt or stock issuance will occur in a merger wave. For overall market valuation, I include the annual forward S\&P 500 PE ratio given the behavioral argument that merger waves are spurred by rising market valuation. Finally, I include deal value with the expectation that higher deal values may correspond with merger waves.

To analyze the structural hypothesis, I include variables that cover industry regulation and economic growth in units and prices. Regulatory includes a dummy variable (Reg) that takes a value of (1) if the merger occurred in those industries (plus Health Services) that Ovtchinnikov (2013) identified to be regulated, and a (0) otherwise. In addition, Regulatory includes the IRR (industry relevant restrictions) index or the IRW (industry relevant words) index, which are continuous variables that cover the annual amount of regulation in each of the 35 industries. Per the structural hypothesis, I hypothesize that merger waves may correlate with deregulation or a lessoning of regulation.

For industry growth I include the Bureau of Economic Analysis (BEA) data covering percent change in prices and the unit chain index (logged) for each of the industries. For the structural hypothesis to hold, I would expect the unit chain index to have a positive impact on the likelihood of a merger wave occurring while the percent change in prices would have a negative impact on the probability of a merger wave. Finally, I include industry category dummy variables for the six key sectors, shown in Table 5. I also interact the commodity sector with percent price change under the expectation that merger waves in the commodity sector are largely spurred by commodity price movements.

In addition, I run a second regression shown in equation (2) to assess whether the merger premium used to effectuate a deal is impacted by a merger wave in additional to the behavioral or structural variables.

$$
\begin{gathered}
\text { MergerPremium }_{j} \log = \\
\beta_{0}+\beta_{1} \text { Wave }_{j}+\beta_{2} \text { Behavioral }_{j}+\beta_{3} \text { Regulatory }_{j} R+\beta_{4} \text { Segment }_{j}+\beta_{5} \text { Economic }_{j}+\varepsilon
\end{gathered}
$$

The expectation is that merger waves spur animal spirits, which can push up merger premiums. Alternatively, merger waves may increase the supply of merger targets, which could push down merger premiums.

Separate regressions were also run using equation 2 to analyze the factors impacting the merger premium based on whether the merger occurred in or out-of-wave. I hypothesize that merger premiums in a merger wave are influenced more by behavioral factors than merger premiums outside of a wave, which I believe will be influenced to a greater extent by structural issues.

\section{Results}

Table 8 shows the results from the logit regression equation analysis (equation 1) with the results listed as marginal effects or change in $y /$ change in x. Columns 1 and 2 list the results from the small and large samples (includes Tobin's Q variables). Separate regressions were run without including Acquirer Tobin's Q or difference in Tobin's Q as there was limited data available on company book value used to calculate acquirer and target Tobin's Q. Columns 3 and 
4 present the results for the small sample (includes Tobin's Q) in regulated and unregulated industries. Columns 5 and 6 then show the result for the large sample (excludes Tobin's Q) for regulated and unregulated industries.

\begin{tabular}{|c|c|c|c|c|c|c|}
\hline $\begin{array}{l}\text { Dependent } \\
\text { var }\end{array}$ & (1) & (2) & (3) & (4) & (5) & (6) \\
\hline Mergerwave & Small Sample & Large Sample & Small Sample & Small Sample & Large Sample & $\begin{array}{l}\text { Large } \\
\text { Sample }\end{array}$ \\
\hline $\begin{array}{l}\text { (Marginal } \\
\text { Effects) }\end{array}$ & & & Regulated & Unregulated & Regulated & Unregulated \\
\hline \multirow[t]{2}{*}{$\begin{array}{l}\text { Acquirer } \\
\text { Tobin's Q } \\
\end{array}$} & $\mid-0.0008$ & & -0.001 & -0.004 & & \\
\hline & $(0.001)$ & & $(0.001)$ & $(0.007)$ & & \\
\hline \multirow[t]{2}{*}{$\begin{array}{l}\text { Target } \\
\text { Tobin's Q } \\
\end{array}$} & 0.001 & & $0.003 * *$ & -0.004 & & \\
\hline & $(0.002)$ & & $(0.001)$ & $(0.006)$ & & \\
\hline \multirow[t]{2}{*}{ ForwardPE } & $0.002^{* * * *}$ & $0.002^{* * * *}$ & $0.002 * * *$ & -0.001 & $0.006^{* * *}$ & -0.001 \\
\hline & $(0.0002)$ & $(0.0003)$ & $(0.001)$ & $(0.001)$ & $(0.001)$ & $(0.001)$ \\
\hline \multirow[t]{2}{*}{$\begin{array}{l}\% \text { Ownership } \\
\log \end{array}$} & 0.02 & $-0.02 *$ & 0.006 & 0.07 & -0.02 & -0.01 \\
\hline & $(0.02)$ & $(0.01)$ & $(0.02)$ & $(0.04)$ & $(0.01)$ & $(0.02)$ \\
\hline \multirow[t]{2}{*}{$\begin{array}{l}\text { Deal Value } \\
\log \end{array}$} & $0.13^{* * *}$ & $0.02 * * *$ & 0.01 & $0.03^{*}$ & $0.019^{*}$ & $0.02 * * *$ \\
\hline & $(0.03)$ & $(0.005)$ & $(0.01)$ & $(0.01)$ & $(0.008)$ & $(0.009)$ \\
\hline \multirow[t]{2}{*}{ Stock issued } & 0.03 & $0.03^{*}$ & 0.05 & $0.16^{* * *}$ & 0.001 & $0.07 * * *$ \\
\hline & $(0.02)$ & $(0.02)$ & $(0.03)$ & $(0.04)$ & $(0.03)$ & $(0.02)$ \\
\hline \multirow[t]{2}{*}{ Borrowing } & -0.046 & -0.006 & -0.01 & 0.04 & $-0.05^{*}$ & $0.03 * *$ \\
\hline & $(0.076)$ & $(0.01)$ & $(0.04)$ & $(0.02)$ & $(0.02)$ & $(0.01)$ \\
\hline \multirow[t]{2}{*}{ Debt issued } & $0.03^{* * *}$ & -0.03 & \begin{tabular}{|l|}
-0.002 \\
\end{tabular} & \begin{tabular}{|l|}
-0.09 \\
\end{tabular} & -0.01 & -0.12 \\
\hline & $(0.008)$ & $(0.03)$ & $(0.05)$ & $(0.09)$ & $(0.04)$ & $(0.10)$ \\
\hline \multirow[t]{2}{*}{ IRR(log)*Reg } & $1.06^{* *}$ & $0.02^{* * *}$ & & & & \\
\hline & $(0.48)$ & $(0.004)$ & & & & \\
\hline \multirow[t]{2}{*}{ IRR index log } & $-0.11 * *$ & $0.59^{* * *}$ & 0.007 & $0.03^{* * *}$ & $-0.04 * * *$ & $0.02^{* * * *}$ \\
\hline & $(0.052)$ & $(0.072)$ & $(0.05)$ & $(0.007)$ & $(0.007)$ & $(0.004)$ \\
\hline \multirow[t]{2}{*}{ Regulated } & $0.32^{* * * *}$ & $-0.06 * * *$ & - & - & - & - \\
\hline & $(0.06)$ & $(0.007)$ & & & & \\
\hline \multirow[t]{2}{*}{$\begin{array}{ll}\text { Unit } & \text { Index } \\
\log & \\
\end{array}$} & -0.002 & $0.30^{* * *}$ & 0.03 & $0.56^{* * *}$ & 0.07 & $0.53^{* * *}$ \\
\hline & $(0.002)$ & $(0.03)$ & $(0.09)$ & $(0.07)$ & $(0.05)$ & $(0.041)$ \\
\hline \multirow[t]{2}{*}{$\begin{array}{ll}\% & \text { Price } \\
\text { change } & \\
\end{array}$} & $0.033^{* *}$ & -0.001 & $-0.01 * * *$ & 0.002 & $-0.008^{* * *}$ & $0.003^{* * *}$ \\
\hline & $(0.014)$ & $(0.001)$ & $(0.006)$ & $(0.0016)$ & $(0.001)$ & $(0.001)$ \\
\hline \multirow[t]{2}{*}{$\begin{array}{l}\text { Commodity } \\
\text { Ind. }\end{array}$} & 0.074 & $-0.12 * * *$ & - & 0.156 & - & 0.08 \\
\hline & $(0.046)$ & $(0.02)$ & & $(0.199)$ & & $(0.06)$ \\
\hline Food \& drug & -0.16 & $-0.08 * * *$ & - & 0.201 & - & $0.12 * *$ \\
\hline
\end{tabular}




\begin{tabular}{|c|c|c|c|c|c|c|}
\hline \multicolumn{7}{|l|}{ Ind. } \\
\hline & $(0.16)$ & $(0.02)$ & & $(0.135)$ & & $(0.058)$ \\
\hline \multirow[t]{2}{*}{ Mfg. Ind. } & -0.082 & $-0.103 * * *$ & - & 0.196 & - & 0.071 \\
\hline & $(0.080)$ & $(0.028)$ & & $(0.132)$ & & $(0.056)$ \\
\hline \multirow{2}{*}{$\begin{array}{l}\text { Business serv. } \\
\text { Ind. }\end{array}$} & -0.069 & $0.036^{*}$ & 0.03 & $0.384 * * *$ & 0.02 & $0.19 * * *$ \\
\hline & $(0.080)$ & $(0.019)$ & $(0.05)$ & $(0.144)$ & $(0.02)$ & $(0.06)$ \\
\hline \multirow[t]{2}{*}{ Financial } & 0.08 & -0.034 & -0.03 & - & $-0.09 * * *$ & - \\
\hline & $(0.06)$ & $(0.021)$ & $(0.03)$ & & $(0.02)$ & \\
\hline \multirow{2}{*}{$\begin{array}{l}\text { Commodity * } \\
\text { Price }\end{array}$} & $0.03^{* *}$ & $0.0038 * * *$ & - & 0.023 & & $0.008 * *$ \\
\hline & $(0.01)$ & $(0.0013)$ & & $(0.014)$ & & $(0.003)$ \\
\hline Observations & 877 & 3,421 & 352 & 525 & 1,531 & 1,675 \\
\hline $\begin{array}{l}\text { Pseudo } \\
\text { R-squared }\end{array}$ & .16 & .10 & .30 & .23 & .15 & .13 \\
\hline
\end{tabular}

Table 8. Regression results

Robust standard errors in parentheses: $\quad * * * \mathrm{p}<0.01, * * \mathrm{p}<0.05, * \mathrm{p}<0.1$

From column 1 we see mixed results regarding the behavioral variables as the coefficient for acquirer Tobin's Q is insignificant, but the coefficient for the target's Tobin's $Q$ is significant in the small regulated sample. This finding would suggest that amount mergers in industries categorized as regulated, increasing the Tobin's Q raises the likelihood of a merger wave ensuing. Also, we see in Table 8, the coefficients for forward PE, deal value and stock issuance as well as debt issuance and borrowing in many of the regressions are positive and significant. These results indicate that merger waves are more likely to occur when the forward PE for the S\&P 500 is high, deal values are relatively large, and when stock or debt is issued to finance the deal. The effect of borrowing appears to vary depending on the industry, as the coefficient for borrowing is positive for unregulated industries and negative for regulated industries. Overall, these findings tend to support the behavioral hypothesis that merger waves ensue in overvalued markets when stock issuance is used to finance the deal as predicted by Rhodes-Kropf and Viswanathan (2004), Harford (2004) and Andrade et. al. (2002). In addition, it seems that merger waves are accompanied by an increase in deal size. These findings regarding the behavioral variables are similar between columns 1 (small sample) and column 2 (large sample), except the coefficient for stock issuance is insignificant in the smaller sample.

When considering the structural hypothesis we should evaluate the significance of the regulatory and economic variables. Here, we see in column 2 that the coefficient for the unit index logged is positive, significant, and quite large. This finding suggests that the larger the annual, growth rate in the 3-digit NAICS industry, the greater the probability of a merger wave occurring. In looking at the breakout between regulated and non-regulated industries, we see that the effect of the unit index is only significant in the non-regulated industries, perhaps suggesting that unit growth fluctuation or potential is limited in the industries classified as regulated.

I also find the coefficient for percent change in the price index in the 3-digit NAICS industry to be positive, and significant in column 1 and insignificant in column 2. The finding from column 1 indicates that declining prices in an industry could spur a merger wave. When looking at columns 3 through 6 we see negative coefficients for change in price in the regulated industries (columns 3 and 5) and a positive coefficient at least in the large sample in the non-regulated industry. This result indicates that industry participants may be more active in combatting price changes through industry consolidation, which leads to a merger wave, in regulated versus non-regulated industries.

I also interacted percent change in price with the commodity group, under the assumption that fluctuating industry prices would more likely induce a merger wave in commodity industries than other segments. Accordingly, we find the 
coefficient for the interactive term between percent change in price and commodity to be positive and significant in the large sample, indicating that changing prices would more likely impact the probability of a merger wave occuring in the commodity sector. The coefficient for the interactive term, however, in column 2 is not quite significant.

Next, I look at the effect of regulation on merger waves. Here, we see that the coefficient for the IRR index (logged) is positive and significant in column 2 and negative and significant in column 1. Similarly, the coefficient for regulation (Reg) is also positive and significant in column 1 and negative and significant in column 2. The effect of regulation and the index is best determined by looking at the coefficient for the interactive term (regulation * IRR-logged), which is positive and significant in both columns 1 and 2, suggesting that increasing regulation in a regulated industry increases the likelihood of a merger. This result suggests that the likelihood of a merger wave increases with increasing regulation in regulated industries. This result seems to run counter to Ovtchinnikov (2013) argument that merger waves are spurred by deregulation, which is a function of poorly performing industries. This difference, however, can be explained by examining the results in the small and large samples restricted to the regulated and unregulated industries in columns 3 through 6 . Here, we see that the coefficient for the IRR index (logged) is negative and significant in the regulated sample (column 5) and positive and significant in the non-regulated samples (columns 4 and 6). This finding would suggest that while being in a regulated industry would increase the probability of a merger wave occurring, decreasing the actual amount of regulation in these regulated industries (e.g. utilities or banking) would have a positive effect on the likelihood of a merger wave ensuing as suggested by Ovtchinnikov (2013). In contrast, decreasing the amount of regulation in unregulated industries appears to decrease the likelihood of a merger wave ensuing, perhaps because increasing regulation suggests changes in industry rules, which could prompt companies to seek out mergers to take advantage of the changes.

Finally, the results from Table 8 indicate that the industry group does affect the likelihood of a merger wave. In the large sample (column 2) we see the coefficients for the commodity and manufacturing sectors to be negative and significant suggesting that being in those sectors reduces the likelihood of a merger wave. In contrast, the coefficient for the Business Service industry is positive and significant in both the small and large sample suggesting that being in this sector has a positive effect on the likelihood of a merger wave. We see this finding in the non-regulated industries in both the large and small sample.

In summary, the likelihood of a merger wave occurring is influenced by both structural and behavioral factors, but the structural factors appear to have a greater impact given the size of the unit index (logged) and IRR index (logged) coefficients as well as the consistency of their effects in each regression. More importantly, there are differences in the factors impacting the likelihood of a merger wave depending on whether the industry is regulated or not. For regulated industries percent price change appears to have a negative impact on the likelihood of a merger wave ensuing while in non-regulated industries, unit growth has a positive impact on the likelihood of a merger wave occurring. Similarly, stock issuance only has a positive impact on a merger wave occurring in unregulated industries. Finally, the volume of regulation as shown in the IRR index has a negative impact on the likelihood of a merger wave occurring in a regulated industry, but a positive impact in an unregulated industry.

In Table 9, we look at the effect that merger waves and other factors have on the prices paid for mergers as indicated by the merger premium. Here, I find the the control variables, percent ownership and deal value (in columns 2 and 6 only), to have a positive, significant effect on the merger premium. These results are similar to those found in other studies (See Sonenshine and Reynolds, 2014). Also, I find that the coefficient for merger wave, the primary variable of interest, is weakly, significant in the large sample suggesting that being in a merger wave reduces the merger premium though only $0.115 \%$. This result is somewhat surprising since it would seem that a merger wave would bid up the prices paid for targets. Alternatively, in accordance with Ovtchinnikov's (2013) argument, merger waves may result from deregulation, which is accompanied by higher cash financing and lower merger premiums. 


\begin{tabular}{|c|c|c|c|c|c|c|}
\hline $\begin{array}{l}\text { Dependent } \\
\text { Variable } \\
\text { Deal Premium }\end{array}$ & Small Sample & Large Sample & $\begin{array}{l}\text { Small Sample } \\
\text { In-wave }\end{array}$ & $\begin{array}{l}\text { Small Sample } \\
\text { Out-of-wave }\end{array}$ & $\begin{array}{l}\text { Large Sample } \\
\text { In-wave }\end{array}$ & $\begin{array}{l}\text { Large Sample } \\
\text { Out-of-wave }\end{array}$ \\
\hline \multirow[t]{2}{*}{ mergerwave1 } & 0.0508 & $-0.115^{*}$ & & & & \\
\hline & $(0.106)$ & $(0.0655)$ & & & & \\
\hline \multirow{2}{*}{$\begin{array}{l}\text { Acquirer Tobin's } \\
\text { Q }\end{array}$} & 0.0001 & & -0.01 & $0.001^{*}$ & & \\
\hline & $(0.0001)$ & & $(0.01)$ & $(0.0005)$ & & \\
\hline \multirow[t]{2}{*}{ Target Tobin's Q } & 0.0001 & & $4.14 \mathrm{e}-05$ & $0.002^{*}$ & & \\
\hline & $(0.0001)$ & & $(0.0003)$ & $(0.001)$ & & \\
\hline \multirow[t]{2}{*}{ ForwardPE } & -0.002 & -0.0009 & -0.015 & -0.001 & -0.005 & 0.0007 \\
\hline & $(0.002)$ & $(0.001)$ & $(0.014)$ & $(0.002)$ & $(0.006)$ & $(0.001)$ \\
\hline \multirow[t]{2}{*}{$\%$ Ownership log } & $0.25 * *$ & $0.23 * * *$ & $-0.53^{* *}$ & $0.32 * * *$ & 0.10 & $0.2 * * *$ \\
\hline & $(0.10)$ & $(0.061)$ & $(0.25)$ & $(0.11)$ & $(0.23)$ & $(0.06)$ \\
\hline \multirow[t]{2}{*}{ Deal value $\log$} & 0.0009 & $0.069^{* * *}$ & -0.041 & 0.024 & -0.028 & $0.08 * * *$ \\
\hline & $(0.038)$ & $(0.026)$ & $(0.072)$ & $(0.04)$ & $(0.06)$ & $(0.02)$ \\
\hline \multirow[t]{2}{*}{ Stock } & -0.021 & -0.05 & $0.46^{*}$ & -0.17 & 0.13 & -0.08 \\
\hline & $(0.150)$ & $(0.08)$ & $(0.24)$ & $(0.18)$ & $(0.23)$ & $(0.08)$ \\
\hline \multirow[t]{2}{*}{ Borrow } & 0.068 & $0.10 * *$ & -0.014 & 0.08 & 0.10 & 0.10 ** \\
\hline & $(0.071)$ & $(0.04)$ & $(0.23)$ & $(0.07)$ & $(0.17)$ & $(0.04)$ \\
\hline \multirow[t]{2}{*}{ Debt } & $0.35 * *$ & -0.0006 & -0.30 & $0.43 * *$ & 0.16 & -0.07 \\
\hline & $(0.15)$ & $(0.20)$ & $(0.25)$ & $(0.17)$ & $(0.20)$ & $(0.24)$ \\
\hline \multirow[t]{2}{*}{ IRR index log } & 0.013 & -0.013 & -0.10 & 0.01 & -0.06 & -0.007 \\
\hline & $(0.03)$ & $(0.029)$ & $(0.32)$ & $(0.03)$ & $(0.17)$ & $(0.03)$ \\
\hline \multirow[t]{2}{*}{ Regulated } & -1.77 & $1.59 * * *$ & -3.76 & -2.02 & & $1.47 * * *$ \\
\hline & $(1.22)$ & $(0.31)$ & $(3.59)$ & $(1.30)$ & & $(0.32)$ \\
\hline \multirow[t]{2}{*}{ IRR(log)*Reg } & 0.16 & $-0.145^{* * *}$ & 0.48 & 0.17 & -0.18 & $-0.13 * * *$ \\
\hline & $(0.12)$ & $(0.033)$ & $(0.38)$ & $(0.13)$ & $(0.20)$ & $(0.03)$ \\
\hline \multirow[t]{2}{*}{ Unit Index log } & -0.36 & -0.14 & 0.35 & $-0.46^{* *}$ & 0.51 & $-0.22 *$ \\
\hline & $(0.24)$ & $(0.14)$ & $(0.87)$ & $(0.23)$ & $(0.65)$ & $(0.13)$ \\
\hline
\end{tabular}




\begin{tabular}{|c|c|c|c|c|c|c|}
\hline$\%$ Price change & 0.013 & $0.009^{*}$ & -0.005 & $0.022 * *$ & 0.01 & $0.009 *$ \\
\hline & $(0.009)$ & $(0.005)$ & $(0.028)$ & $(0.01)$ & $(0.01)$ & $(0.005)$ \\
\hline \multirow[t]{2}{*}{ Commodity Ind. } & -0.018 & $1.127 * * *$ & $2.74 * * *$ & -0.20 & $1.48^{* *}$ & $1.04 * * *$ \\
\hline & $(0.35)$ & $(0.10)$ & $(0.99)$ & $(0.37)$ & $(0.61)$ & $(0.10)$ \\
\hline \multirow[t]{2}{*}{ Food \& drug Ind. } & $0.44 * *$ & $0.520 * * *$ & $2.10 * *$ & 0.27 & 1.00 & $0.45^{* * *}$ \\
\hline & $(0.22)$ & $(0.13)$ & $(1.03)$ & $(0.22)$ & $(0.64)$ & $(0.14)$ \\
\hline \multirow[t]{2}{*}{ Mfg. Ind. } & $0.33^{*}$ & 0.30 ** & $1.40 * * *$ & 0.19 & $0.70^{*}$ & $0.22 *$ \\
\hline & $(0.20)$ & $(0.12)$ & $(0.49)$ & $(0.21)$ & $(0.36)$ & $(0.13)$ \\
\hline \multirow[t]{2}{*}{$\begin{array}{l}\text { Business serv. } \\
\text { Ind. }\end{array}$} & $0.35 * *$ & 0.11 & $0.79 *$ & $0.37 * *$ & 0.28 & 0.087 \\
\hline & $(0.15)$ & $(0.11)$ & $(0.44)$ & $(0.16)$ & $(0.31)$ & $(0.12)$ \\
\hline \multirow[t]{2}{*}{ Financial } & -0.13 & $0.40^{* * *}$ & 0.19 & -0.072 & 0.51 & $0.37 * * *$ \\
\hline & $(0.17)$ & $(0.10)$ & $(0.89)$ & $(0.17)$ & $(0.35)$ & $(0.11)$ \\
\hline Constant & $6.619 * * *$ & $5.352 * * *$ & 7.355 & $6.679 * * *$ & 3.462 & $5.55^{* * *}$ \\
\hline Observations & 728 & 1,693 & 118 & 610 & 256 & 1,437 \\
\hline R-squared & 0.086 & 0.194 & 0.304 & 0.108 & 0.212 & 0.194 \\
\hline
\end{tabular}

Table 9. Regression results

Robust standard errors in parentheses: $* * * \mathrm{p}<0.01, * * \mathrm{p}<0.05, * \mathrm{p}<0.1$

I also find that the method of financing has an effect on the deal premium, with differences observed between the in-wave and out-of-wave sample. In the in-wave sample the coefficient for stock issuance is positive and weakly significant, indicating that mergers in-wave that are financed via stock issuance tend to result in higher merger premiums. Conversely, I find the coefficients for debt and borrowing to be significant in columns 4 and 6 respectively suggesting that mergers that are out-of-wave that are financed by debt or borrowing tend to result in higher merger premiums.

In the total large sample, I also find the coefficient for percent change in price to be positive and significant, suggesting, as expected, that rising prices in an industry would lead to higher merger premiums paid. I see this effect in the out-of-wave sample for both the small and large samples; however, I do not find this effect in the in-wave samples. Similarly I see the coefficient for the log of the unit index to be negative and significant in the out-of-wave samples (column 4 and 6), indicating that lower merger premiums are paid in faster growing markets out of merger waves. It is notable that I don't see the effects of industry price and quantity changes on the merger premium in the in-wave merger samples.

I also find the coefficient for acquirer and target Tobin's Q to be positive and weakly significant in the out-of-wave merger sample (Column 4). These findings provide limited evidence that valuation metrics are influencing the merger premium; however, the effect only occurs in out-of-wave mergers and the coefficients are small and weakly significant.

In the in-wave merger sample I find the coefficient for stock financing to be significant indicating that merger premiums are higher the larger the percent of stock financing. This finding is consistent with previous studies, but I only 
find it to occur in the in-wave sample..

Next, I turn to the effect of regulation on the deal premium. Here, I find in column 2 that the coefficient for Regulation is positive and significant suggesting that premiums are $1.56 \%$ higher in regulated industries. This effect only seems to occur out of a merger wave, as the coefficient for regulation is only significant in column 6 , the out-of-wave sample. I also find, the coefficient for the IRR index (logged) interacted with regulation to be negative and significant in the large sample and the large, out-of-wave sample, suggesting that merger premiums decline as the index of regulation increases for out-of-wave mergers occurring in regulated industries.

In summary there is limited evidence that merger waves have a negative impact on merger premiums. I also find that the factors that affect merger premiums differ between in and out-of-wave mergers. With out-of-wave mergers there is evidence that acquirers respond to structural factors to include growth in prices, unit volume, and regulation. For out-of-wave mergers acquirers may also respond somewhat to valuation metrics as shown by acquirer and target Tobin's Q. For inwave mergers it seems that merger premiums are primarily a function of the industry as well as the mthod of financing (e.g. stock financing).

\section{Conclusions}

This study examines the effect that behavioral and structural factors have on the likelihood of a merger wave ensuing as well as on the deal premium paid to consummate a merger. The paper contributes to the literature by assessing the factors that lead to a merger wave across all industries and analyzing the differential impact of these factors based the level of regulation in the industry. In addition, this paper is unique in that it assesses differences in acquirer behavior as measured by the deal premium in and outside of a merger wave.

I find that while both structural and behavioral factors impact the likelihood of a merger wave occuring, economic factors, consisting of change in unit and price growth, along with regulatory measures, appear to have the stronger, more consistent effect on the likelihood of a merger wave ensuing. In addition, the results indicate that the factors differ by industry segment with increasing growth and regulation along with stock issuance having a positive impact on the likelihood of a merger wave in non-regulated industries, while decreasing regulation and change in industry price, along with increased market valuation as measured by forward PE, increase the probability of a merger wave occuring in regulated industries.

Regarding the deal premium, I find limited evidence that a merger wave negatively impacts premiums paid. Also, the results indicate that structural concerns appear to have more of an impact on the merger premium among mergers outside of a merger wave. The merger premium for in-wave mergers is primarily driven by the industry.

In summary, both structural and behavioral hypotheses have their place in explaining merger waves. It is difficult to generalize on the causes of a merger wave since industry composition, such as regulated versus non-regulated industries, plays a key role. I leave it up to other research to explore other factors that might spur a merger wave overall and in specific industry segments. 


\section{Appendix}

\begin{tabular}{|c|c|c|c|c|}
\hline Industry Category & Industries & $\begin{array}{l}\text { Mergers by } \\
\text { industry }\end{array}$ & $\begin{array}{l}\text { Year of Merger } \\
\text { Waves }\end{array}$ & $\begin{array}{l}2 \text { year average in } \\
\text { merger wave }\end{array}$ \\
\hline Commodities & $\begin{array}{l}\text { Mining } \\
\text { Oil and gas } \\
\text { Wood products } \\
\text { Paper products } \\
\text { Total }\end{array}$ & $\begin{array}{l}156 \\
483 \\
13 \\
60 \\
712\end{array}$ & $\begin{array}{l}2010 / 2011 \\
\text { None } \\
\text { None } \\
2007\end{array}$ & $\begin{array}{l}43 \\
- \\
- \\
16 \\
59(8 \%)\end{array}$ \\
\hline Food, Drug, and Household & $\begin{array}{l}\text { Pharmaceutical } \\
\text { Food products } \\
\text { Soaps and personal care } \\
\text { Textile and apparel } \\
\text { Tobacco } \\
\text { Total }\end{array}$ & $\begin{array}{l}353 \\
81 \\
245 \\
395 \\
388 \\
579\end{array}$ & $\begin{array}{l}2007 / 2008 \\
2006 / 2007 \\
2016 / 2017 \\
2016 / 2017 \\
2005\end{array}$ & $\begin{array}{l}63 \\
14 \\
6 \\
8 \\
6 \\
85(15 \%)\end{array}$ \\
\hline Financial Services & $\begin{array}{l}\text { Commercial banks } \\
\text { Credit institutions } \\
\text { Insurance } \\
\text { Investment firms } \\
\text { Real estate } \\
\text { Savings and loan banks } \\
\text { Total }\end{array}$ & $\begin{array}{l}353 \\
81 \\
245 \\
395 \\
388 \\
25 \\
1,487\end{array}$ & $\begin{array}{l}2007 / 2008 \\
2006 / 2007 \\
2007 \\
2006 / 2007 \\
2007 / 2008 \\
\text { None }\end{array}$ & $\begin{array}{l}63 \\
14 \\
24 \\
72 \\
81 \\
- \\
254(17 \%)\end{array}$ \\
\hline $\begin{array}{l}\text { Consumer services (B2C) } \\
\text { Businesss Services (B2B) }\end{array}$ & $\begin{array}{l}\text { Amusement and recreation } \\
\text { Hotels and casinos } \\
\text { Electric, gas, water } \\
\text { Repair services } \\
\text { Sanitation services } \\
\text { Total } \\
\text { Air Transport and shipping } \\
\text { Business services / adverti } \\
\text { Printing and publishing } \\
\text { Telecommunications } \\
\text { Health services } \\
\text { Motion pictures production } \\
\text { Retail trade } \\
\text { Construction } \\
\text { Sub Total } \\
\text { Overall total }\end{array}$ & $\begin{array}{l}51 \\
78 \\
343 \\
450 \\
15 \\
510 \\
49 \\
41 \\
374 \\
90 \\
343 \\
64 \\
60 \\
64 \\
60 \\
1,070\end{array}$ & $\begin{array}{l}2015 / 2016 \\
2006 / 2007 \\
2000 \\
2007 \\
2015 \\
2012 / 2013 \\
\text { None } \\
\text { None } \\
2007 \\
2000 / 2001 \\
2015 / 2016 \\
2005 / 2006 \\
2007\end{array}$ & $\begin{array}{l}11 \\
26 \\
48 \\
7 \\
- \\
92(18 \%) \\
13 \\
- \\
- \\
26 \\
61 \\
21 \\
6 \\
14 \\
11 \\
141(14 \%)\end{array}$ \\
\hline Manufacturing & $\begin{array}{l}\text { Chemicals } \\
\text { Rubber products } \\
\text { Aerospace and aircraft }\end{array}$ & $\begin{array}{l}160 \\
35 \\
36\end{array}$ & $\begin{array}{l}\text { None } \\
2007 \\
2008\end{array}$ & $\begin{array}{l}- \\
7 \\
8\end{array}$ \\
\hline
\end{tabular}




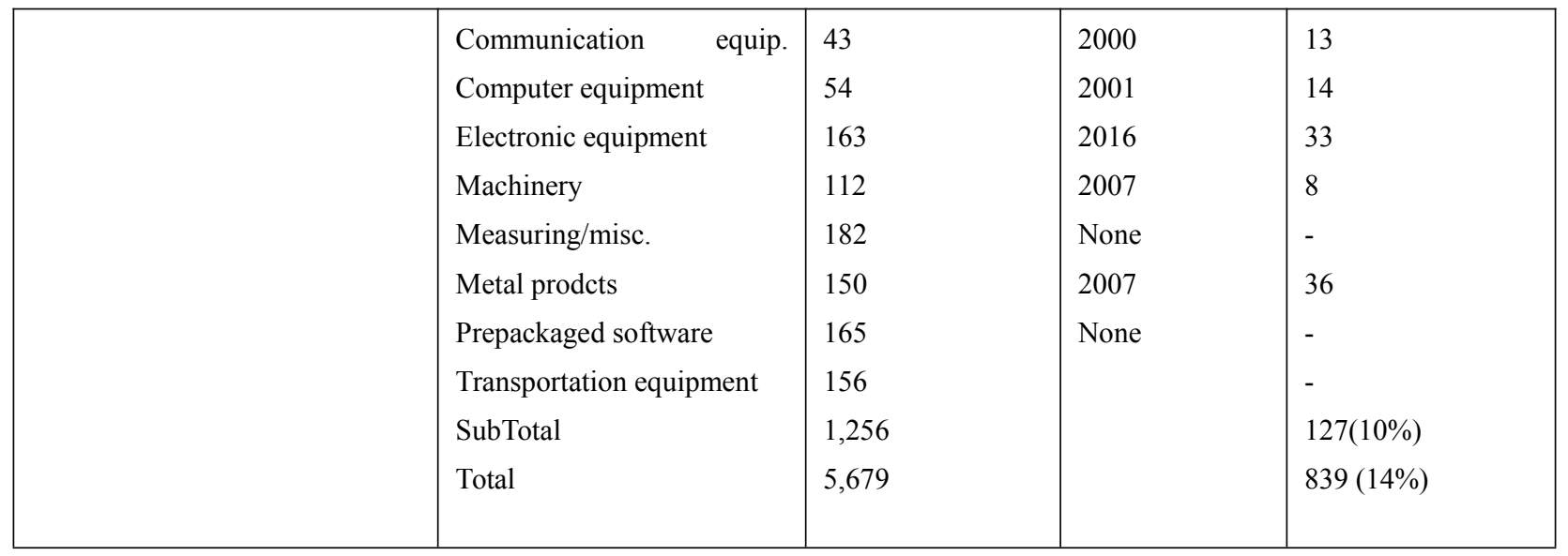

\section{References}

1. Andrade G, Mitchell M, Stafford E. New evidence and perspectives on mergers? Journal of Economic Perspectives 2001; 15, 103-120.

2. Brealey, Richard A, Stewart C. Myers. Principles of corporate finance. 1st ed. New York, NY: McGraw-Hill Education1996.

3. Gugler K, Mueller D, Weichselbaumer M. The determinants of merger waves: An international perspective. International Journal of Industrial Organization 2012; 30(1): 1-15.

4. Harford J. What drives merger waves? Journal of Financial Economics 2005; 77,529-560.

5. Jovanovic Boyan, Peter Rousseau. The Q-theory of mergers. American Economic Review 2002; 92, $198-204$.

6. Mitchell M, Mulherin M. The impact of industry shocks on takeover and restructuring activity. Journal of Financial Economics 1996; 41(2):193-229.

7. Rhodes-Kropf M, Viswanathan S. Market valuationa and merger waves. The Journal of Finance 2004; 59(6): 2685-2718.

8. Roll R. The hubris hypothesis of corporate takeovers. The Journal of Business 1986; 59(2): 197-216.

9. Shleifer A, Vishny R. Stock market driven acquisitions. Journal of Financial Economics 2003; 70, $295-311$.

10. Sonenshine R, Reynolds K. Determinants of cross border merger premia. Review of World Economics 2014; 150(1): 173-189.

11. Ovtchinnikov A. Merger waves following industry deregulation. Journal of Corporate Finance 2013; 21, 41-76.

12. Verter G. Timing merger waves. Harvard University, Mimeo 2002. 